\title{
Organizasyonel Yeniliğin ve Personel Güçlendirmenin İş Performansına Etkisi: Bir Sanayi Firması Uygulaması (The Effect of Organizational Innovation and Employee Empowerment on Job Performance: A Case of an Industrial Firm)
}

\author{
Gönül KONAKAY iD a Ali AKDEMİ iD b Ayşe Çiğdem MERCANLIOĞLU iD c \\ a Kocaeli Üniversitesi, Hereke Ö.İ. Uzunyol Meslek Yüksekokulu, Kocaeli, Türkiye. gkonakay@hotmail.com \\ b İstanbul Arel Üniversitesi, İktisadi ve İdari Bilimler Fakültesi, İstanbul, Türkiye. aliakdemiral@gmail.com \\ c İstanbul Bilgi Üniversitesi, Sağlık Bilimleri Fakültesi, Sağlık Yönetimi Bölümü, İstanbul, Türkiye cigdem.mercanlioglu@bilgi.edu.tr
}

\begin{tabular}{|c|c|}
\hline MAKALE BİLGİSİ & ÖZET \\
\hline $\begin{array}{l}\text { Anahtar Kelimeler: } \\
\text { İnovasyon } \\
\text { Personel Güçlendirme } \\
\text { İş performansı }\end{array}$ & $\begin{array}{l}\text { Amaç - Günümüzde işletmelerin yenilik performanslarını arttırabilmeleri yeteneklerine güvenilen iş } \\
\text { görenlerin yaratıcı düşüncelerini açığa çıkarmaları ile mümkün olabilmektedir. Çalışanlarda yaratıcı fikirlerin } \\
\text { açı̆ga çımasııı sağlayan örgütler rekabet ortamında ayakta kalmayı başaracaklardır. Personel güçlendirme } \\
\text { ile hem iş performansı hem de organizasyonel yenilik performansı değişim gösterecektir. Bu araştırmanın } \\
\text { amacı, personel güçlendirme ve organizasyonel yeniliğin çalışan performansı üzerindeki etkilerini } \\
\text { incelemektir. }\end{array}$ \\
\hline
\end{tabular}

Gönderilme Tarihi 2 Ocak 2021

Revizyon Tarihi 17

Mart 2021

Kabul Tarihi 27 Mart 2021

Makale Kategorisi: Araştırma Makalesi
Yöntem - Kocaeli ilinde faaliyet gösteren Arçelik A.Ș.'nin yan sanayi ürünlerini oluşturan Tekkan A.Ş.'nin 300 çalışanına anket uygulaması yapılmıştır. Eksiksiz gelen 175 anket değerlemeye alınmıştır. Çalışanların organizasyonel yenilik performansı Wang ve Ahmet'in 2004 yılında geliştirdiği 17 soruluk Organizasyonel Yenilik Ölçeği ile ölçülmüştür. Çalışanlarda personel güçlendirme ölçümünde Spreitzer'in (1995) anlam, yeterlilik, seçim ve etki boyutlarından oluşan 12 soruluk Psikolojik Güçlendirme Ölçeği kullanılmıştır. İş performansı ise 4 sorudan oluşan Kirkman ve Rosen (1999) ölçeği ile ölçülmüştür. Verilerin analiz edilmesinde SPSS programı kullanılmıș, tüm ölçekler için geçerlik ve güvenilirlik analizleri yapılmıştır. Çalışmada değişkenler arası ilişki ve etki düzeyini ölçmek amaçlı faktör analizi, korelasyon ve regresyon analizleri yapılmıştır.

Bulgular - Araştırma sonucunda, personel güçlendirmenin organizasyonel yenilik performansı ve iş performansı üzerinde etkisinin olduğu görülmüştür.

Tartışma - Organizasyonel yenilik faktörleri olan süreç ve ürün yeniliği, davranışsal yenilik ve stratejik yenilik ile iş performansı arasında ilişki tespit edilmeye çalışılmış ve Personel güçlendirme faktörleri olan anlam faktörü, seçim faktörü, etki faktörü ve yeterlilik faktörü ile iş performansı arasındaki ilişki irdelenmiştir.

\section{ARTICLE INFO}

ABSTRACT

\section{Keywords:}

Innovation

Employee

empowerment

Job performance

Received 2 January 2021

Revised 15 March 2021

Accepted 27 March 2021

Article Classification:

Research Article
Purpose - Today it can be possible for the firms to increase their innovation performance when the employees whose talents are needed reveal their creative thoughts and ideas. Organizations that enable employees to reveal their creative ideas will be able to survive in the competitive environment. Both job performance and organizational innovation performance will change with employee empowerment. The purpose of this study is to examine the effects of employee empowerment and organizational innovation on job performance.

Design/methodology/approach - In this study, a questionnaire was administered to 300 employees of Tekkan Inc, which is operated in Kocaeli and produces byproducts of Arçelik Inc. 175 complete questionnaires were included in the study. Organizational innovation performance of the employees was measured by using the 17-item organizational innovation scale developed by Wang and Ahmet (2004). To measure employee empowerment, Spreitzer's (1995) Psychological Empowerment Scale - a 12-item questionnaire with the dimensions of meaning, competence, self-determination and impact- was used. Job performance was measured by using the 4 -item job performance scale developed by Kirkman and Rosen (1999). SPSS program was used to analyze the data, and validity and reliability analyses were carried out for all scales. In the study, factor analysis, correlation and regression analyses were performed to measure the relationship and impact level of the variables.

Findings - As a result of the research, employee empowerment and organizational innovation performance were found to have an effect on job performance.

Discussion - The relationship between organizational innovation factors such as process and product innovation, behavioral innovation and strategic innovation and job performance has been tried to be determined, and the relationship between employee empowerment factors such as meaning factor, selection factor, impact factor and competence factor and job performance has been investigated. 


\section{Gìiș}

Yenilik, karlılık ve nakit akışında üstünlük sağlayan ve rakiplere karşı işletmeyi rekabette güçlü kılan en etkin yol ve güçlü bir rekabet silahıdır. Yenilik, organizasyondaki çalışanlar ve diğer uygulayıcılar tarafından yeni olarak kabul edilen düşünce, uygulamalar veya nesnelerdir (Tekin, Güleş, Öğüt, 2003). Ahmed'e göre yenilik, işletmenin çevrede meydana gelen değişimlere uyum sağlayabilmesi için örgüt kültürüne değer yaratmasıdır. Yenilik (inovasyon) bir anlamda, örgüt kültürünün bir öncüsü olarak algılanmalı, işletmenin iç ve dış çevresindeki sürekli değişimlere uyum sağlayabilmesi için bir avantaj olarak kullanılabilmelidir. Örgüt kültürünün yapısı, aynı zamanda işletmenin inovasyon anlayışını da belirleyebilmektedir (Ahmed, 1998).

"Yenilik" ile "yaratıcılı" birbirlerinin yerine kullanılsa da aralarında küçük bir fark bulunmaktadır; Başarıll, yaratıc fikirlerin bir uygulaması yenilik olarak tanımlanmaktadır. Yaratıcılık ve yenilik organizasyon çalışanları tarafından gerçekleştirilmektedir, kendi kendine oluşan bir şey değildir (Cummings \& Oldham, 1997). Yenilikçi firmalar müşterilerinin isteğini içgüdüsel olarak anlar ve işletme performansının artması için gerekli yenilikleri yaparlar (Tidd, Bessant, \& Pavitt, 2001).

Yöneticilerin yenilik sürecinde etkili olan bireysel ve örgütsel unsurları tanımasında ve etkin bir şekilde yönetmesinde organizasyon için büyük yarar vardır. Bu unsurlar; yeniliğe verilen önem, adalet, belirsizlik, riske karşı tolerans tutumları vb. dir (Shalley ve Gilson, 2004).

Örgüt içerisinde liderlerin yeniliği destekleme davranışlarında bir azalma veya desteklememe olursa, çalışanlarda yenilikçi çabalarını sona erdirebilirler (Krause, 2004 ). Bu da lider için büyük bir risk unsurudur. Yeniliği tek başına bireylerin özellikleri etkilememektedir. Çalışanlar üstlendikleri riskleri ve elde ettikleri kazanımları beklentileriyle kıyaslamaktadır. Bu da çalışanların yenilikçi iş davranışlarını ve dolayısıyla performanslarını etkilemektedir (Yuan \& Woodman, 2010). Liderlerin çalışanlarını yenilikçi davranışlar konusunda cesaretlendirmeleri ve çalışanların beklentilerini gerçekleştirme çabalarında sağladıkları güven ortamı organizasyonel yeniliği arttıracağı gibi personel motivasyonunu da arttıracaktır.

Literatürde ulusal yenilik sistemlerinin kurulması ve bunların sürdürülebilir olması yolunda çalışmalar yapanlar (Freeman 1989; Nelson, 1993; Lundvall, 2010) yenilik sistem modellerinin kurulmasina katk1 sağlamıştır. Nelson (1993) çalışmasında yenilik sistemlerinin kurulması için yapısal, işlevsel ve etkinlik yaklaşımlarının kurulması gerekliliğini vurgulamaktadır. Yapısal yaklaşım yeni teknolojilerin üretimi, kullanımı ve yaygınlaştıııldığı yapıların kurulmasıdır. İşlevsel yaklaşımda, bilginin üretimi ve erişiminin kolaylaşması için gerekli ağ yapılarının oluşturularak gerekli kaynakların hazır hale getirilmesidir. Sistem içinde yer alan tüm paydaşların çeşitli ulusal politikalar ile koordine edilmesi ise etkinlik yaklaşımıdır (Kara, 2019).

$\mathrm{Bu}$ araştırma ile personel güçlendirme ve organizasyonel yeniliğin çalışan performansı üzerinde bir etkisinin olup olmadığının incelenmesi amaçlanmıştır. İşletmenin hayatının sürdürülebilirliğinde, teknolojiyi yaratmasında, kullanılmasında en etkin güç olan insan kaynağının güçlendirilerek yapılan organizasyonel yeniliklerin çalışan performansındaki etkilerinin tespit edilmesi büyük önem arz etmektedir. Çalışmada elde edilecek sonuçların bu konuda genişleyen literatüre katkı sağlayacağı düşünülmektedir.

\section{KAVRAMSAL ÇERÇEVE}

Çalışmanın bu bölümünde personel güçlendirme, organizasyonel yenilik ve çalışan performansına yönelik kavramsal çerçeve sunulmuş ve personel güçlendirme ve organizasyonel yeniliğin çalışan performansı üzerindeki etkisine yönelik literatürdeki önceden yapılmış olan çalışmaların bulgularına yer verilmiştir.

\subsection{Organizasyonel Yenilik}

Son yıllarda yapılan çalışmalar, organizasyonel yeniliğin gelişmesine etki eden faktörler ile bu faktörlerin firma performansına etkilerini inceleyen çalışmalardır (Camisón, Villar ve López, 2014). Bu çalışmaların sayısındaki artışı tetikleyen unsur, Oslo Kılavuzu'nda organizasyonel yeniliğin yenilik türü olarak sinıflandırmada ayrı olarak ele alınmasından kaynaklanmaktadır (Eren ve diğ., 2015). 


\section{G. Konakay - A. Akdemir - A.Ç. Mercanlığlu 13/1 (2021) 980-993}

Organizasyonel yenilik, "firmanın ticari uygulamalarında, işyeri organizasyonunda veya dış ilişkilerinde, firmada daha önce kullanılmamış ve yönetim tarafından alınan stratejik kararların bir sonucu olan yeni bir organizasyonel yöntemin uygulanmasıdır" (OECD, 2005).

Günümüz iş hayatında ve sosyal hayatta; yeniliklerin yüzeysel incelenmesinden ziyade detaylı ve çoklu boyutlu yaklaşımlar sergilenmesi gerekmektedir. Boyutları değerlendirirken; yeniliklerin uygulamaya geçilmeden önceki aşamaları oldukça önemlidir. Uygulama kısmının pratikleri ve emsali nispeten daha belirgindir. Ancak örgütlerin bu yeniliklere karşı algıları ve bunun etken parametrelerinin varlığı veya oluşumu örgütten örgüte farklı ve tutarsızdır. Bu etken ve etkili olan faktörlerin iyi değerlendirilmesi, özellikle çalışma sonucunda ortay çıkan etkili boyutların irdelenmesi, işletmelerdeki yenilikçi iş performansına direk etki edecek, yeniliklerin uygulama ve sonrasında denetleme esnasındaki süreçleri daha belirgin ve az riskli olacaktır.

Yenilik yapmak için örgütlerde yenilik yapmaya yönelik politika ve uygulamaların örgüt çalışanları ve yapıları ile bütünleştirilmesi gerekmektedir. Dâhilerini kaybeden ulusların geleceklerini kaybetmesi gibi, yenilik yapma potansiyeli olan çalışanlarını kaybeden organizasyonlar da geleceklerini kaybetme tehlikesi ile karşı karşıyadırlar (Mert, 2018). Yönetim gurusu Peter Drucker'a göre, yönetimlerin iki işlevi bulunmaktadır: Yenilik yapmak ve yapılan yeniliği pazarlamak (Al-Askari, 2011, aktaran: Karabulut, 2015).

İşletmelerde yeni ürün geliştirme stratejik yaklaşımla, doğrusal bir model çerçevesinde, yeni fikir geliştirmeden ve Ar-Ge'den, yeni ürün pazarlamaya; yeni ürün pazarlamadan, Ar-Ge'ye doğru gerçekleştirilebilir. Diğer bir deyişle, yeni ürün kaynak veya talep eksenli veya karma biçimde gerçekleştirilebilir. Pazarlamadan Ar-Ge'ye, mühendisliğe ve üretime yönelimde, fonksiyonel birimlerin etkileşimiyle, ürünün rekabetçi fonksiyonelliği, mevcut ve olası donanımlarla üretilebilirliği, rekabetçi teknikleri ve testleri geçebilirliği, kaynak uygunluğu ve maliyet etkinliği değerlendirilebilir (Karabulut, 2015).

Schumpeter'e göre girişimciler stratejik üstünlüklerini teknolojik yenilik (yeni bir mal veya hizmet ya da bunu meydana getirmek için yeni bir süreç) kullanabilme becerisini geliştirme fikrini benimseyerek elde edeceklerdir (Tidd ve diğ., 2005).

Son zamanlarda araştırmacılar, teknolojik ürün ve süreç yeniliğine yönelik artan eğilimi eleştirmekte ve yürütülen yeni çalışmalar özellikle teknolojik olmayan organizasyonel yenilik, öncülleri, formları ve sonuçlarını araştırmaktadır (Ganter ve Hecker, 2014). Yenilikçilik faaliyetleri ile işletmeler; yapı, süreç, mal ve hizmetlerinde yaptıkları yeniliklerle maliyetlerin azaltılması, kalitenin yükseltilmesi daha incelikli tüketici istek ve ihtiyaçlarının karşılanması gibi çeşitli avantajları, büyüme ve genişleme aracı olarak kullanmaktadırlar. Bu durum da dolayısıyla ulusal ekonomiye katkıda bulunmaktadır (Eğe, 2002).

Organizasyonel yenilik; işletmelerin organizasyon içinde ve ticari uygulamalarında, organizasyon içinde ve dış ilişkilerinde yeni yöntem ve uygulamaların yapılmasıdır. Pazarlama yeniliği; ürün tasarımından ambalajlamasına, ürün konumlandırmasından tanıtımına ve fiyatlandırmasına kadar bütün önemli değişiklikleri içine alan pazarlamada yeni bir yöntemdir ( Zerenler ve diğ., 2007).

Pazarlama yeniliği; ürünlerin tasarımında, ambalajlanmasında, konuşlandırılmasında, tanıtımında veya ücretlendirilmesinde önemli değişimleri ifade eden yeni pazarlama yöntemlerinin uygulanmasıdır. Pazarlama yenilikleri; müşteri ihtiyaçlarını daha iyi bir şekilde karşılamayı, satışların arttırılması için mevcut ürünlerin pazarlardaki yerini yeniden konumlandırılmasını ve yeni pazarlar oluşturmayı amaçlar (OECD, 2005).

Süreç yeniliği; sürecin hızlanması ve gelişmesi yönünde yapılan her türlü yenilik ve iyileştirme süreç yenilikleri olarak tanımlanmıştır (Bettencourt and Ulwick, 2008). Yeni veya belirgin derecede geliştirilmiş üretim ve teslimat metotlarının uygulanmasına süreç yenliği denilmektedir (OECD, 2005). Süreç yenilikleri uygulamaları birim maliyetin düşürme eğilimleri taşımaktadır. Daha kaliteli üretim sağlanması, üretim ve teslimat süreçlerini kolaylaştırılması ve bu süreçlerde kullanılan teçhizatın geliştirilmesi de süreç yenilikleri arasında gösterilmektedir.

Örgütsel yenilik; işletmedeki teamüllerde, işyeri yapılanmalarında veya işletmelerin çevresiyle olan ilişkilerinde örgütsel yöntemlerde yeni uygulamalar ve bakış açıları geliştirilme sürecidir. Örgütsel yenilikler, yönetim ile ilgili harcamaların azaltılarak, işlem maliyetlerinin düşürülmesi, işyeri memnuniyetinin 


\section{G. Konakay - A. Akdemir - A.Ç. Mercanlığlu 13/1 (2021) 980-993}

arttırılması ve maddi olmayan varlıklardaki erişimin sağlanmasıyla işletmenin performansının ve pazar payını arttırmayı hedeflemektedir. Düzenli olarak yapılan örgütsel faaliyetlere uygulanan yeni yöntemler veya yöntemsel iyileştirmeler örgütsel yeniliktir (Turanlı ve Sarıdoğan, 2010).

Yeniliği benimsemiş organizasyonlarda yenilik süreci ilk olarak yeniliği farkı etme, yeniliği benimseme, değerlendirme, uyarlama gibi kararın verilmesi, denemeler yapılması ve sonunda uyarlamanın yapılmasıdır. Bunun için yenilik süreç, ürün ve servis olarak nitelendirilmektedir (İmamoğlu, 2012).

Özen ve Bingöl'ün (2007), küçük ve orta ölçekli 112 imalat sanayi işletmesi üzerinde yaptığı araştırmada firmaların organizasyonel yenilik oranlarında ürün yeniliği yüzde 56,3'tür. Pazar yeniliği yüzde $45,5^{\prime}$ dir. Yüzde 44,6 ile süreç yeniliği üçüncü sırada yer almaktadır. En son sırada yüzde 42 ile organizasyonel yenilik bulunmuştur. Firmaların eğitim programları düzenlemesi, üretimde ve satışta bilgi teknolojilerini kullanıyor olmaları ve bilgisayar donanımlarına sahip olmaları ile yenilikçilik unsurları arasında anlamlı ilişkiler bulunmuştur.

\subsection{Personel güçlendirme}

Coleman'a göre (1996) personel güçlendirmeye sebep olan faktörler; küresel rekabet ve müşteri isteklerine duyarlılık, yönetimde esneklik ve hızlı olma, işletme hiyerarşisinde yatay yapılanma, kapasite arttırma ve sosyal sorumluluk kavramının personel tarafından benimsenmesi, her birimde risk alma, katılım ve yaratıcıllğın özendirilmesi, yöneticilerin otoritelerini gönüllü olarak delege etmeleri, iletişimde işbirliği ve organizasyonel güvenin artmasıdır.

Yeniliğe destek veren işletmeler yeniliği kurumsallaştıran, örgütün çevresini de yaratıcı hale getiren, yaratıcılığı ve yeniliği ödüllendiren organizasyonlardır. Organizasyon stratejileri yenilikçi hedefler ve sonuçlar üzerine odaklanmaktır (Eminoğlu, 2011). Organizasyon içindeki yenilik yöneliminin kurumsallaşması için çalışanların her düzeyde yaratıcı katılımlarının sağlanması ve çalışanların birbirleri ile işbirliği içinde olmalarıyla gerçekleşecektir.

Organizasyonel yeniliğin gelişmesi sorumluluğunu alan çalışanların çalışma şartları ile kişisel yeterlilikleri ve kişisel ihtiyaçları arasında iyi bir uyum sağlama durumu olmalıdır. Bu sorumluluk örgütün üyeleri ile işbirliği ve iletişimi arttırdığı gibi; daha yüksek iş memnuniyetinin oluşmasını sağlamaktadır (Janssen, 2000).

Personel güçlendirme, küresel değişim ve rekabetin ortaya çıkardığı ve önemini artırdığ kavramıdır (Genç, 2004). Robbins (2002)'ye göre , personel güçlendirme için yapılan tanımlamaların dinamik çevre düşünülerek, basite indirgenmeden göz önüne alınması gereken bir süreç olduğu düşünülmesi gerekmektedir. Yerel iş çevresinin, personel güçlendirme sürecinde genel organizasyon çerçevesinden etkilenen ilk aşaması olduğu kabul edilmektedir. Personelin destek, sadakat, fırsat ve güven gibi bireysel özellikleri ile oluşan algıları örgütsel ve yerel iş çevresi içindeki personel güçlendirmenin bireysel tutumlarını etkilemektedir. Personel güçlendirmenin psikolojik unsurlarından etki, , yeterlik, anlam ve karar verme gibi unsurların davranışa dönüşmesi ile personel güçlendirme süreci tamamlanmış olmaktadır (Robbins, 2002).

\section{3.İşletme Performansı}

Örgütlerin çalışanların yaratıcılıklarını arttırmak için odaklanmaları rekabet etme güçlerine katkı sağlayacaktır. Örgütlerin rekabet güçleri çalışanların sadece teknik yeterlilikleri ve becerilerini geliştirmekle değil, yaratııılıklarını arttırmanın yollarının bulunması ile gerçekleşecektir. Yaratıcılık teşvik edilirken üretilen fikirlerin hayata geçirilmesinde ve uygulanmasında şirket potansiyellerinin yetersizliği "inovasyon açı̆̆ı" olduğu kabul edilen bir gerçekliktir (Aghayeva, 2019).

İşletme performansının ölçülmesi rekabet avantajı yarattığı gibi işletmelerde hayati önem taşımaktadır. Ölçülemeyenin kontrol edilmesi imkansız olduğu gibi yönetilmesi de imkansızdır (Yıldız, 2011).

Reiner (2004) çalışmasında işletme performansını üç grupta nitelendirmiştir. Yatırımın geri dönüşü, karlılık gibi göstergeler "işlevsel performans" olarak ilk boyut olarak ele alınmıştır. İkinci boyut olan "çıktı performansı" göstergeleri pazar payı, satışlardaki artış vb. göstergelerdir. Çıktı performansı ve işlevsel performans kısa dönemli performansdır. Yenilik, yeniliğe uyum sağlayabilme başarısı ise uzun dönemli performansdir. 


\section{G. Konakay - A. Akdemir - A.Ç. Mercanlığlu 13/1 (2021) 980-993}

Literatürde personel güçlendirmenin ve organizasyonel yeniliğin olduğu işletmelerde çalışan performansının nasıl etkilendiğini ölçen çalışma bulunmamaktadır. Bu yüzden araştırma modelimizde çalışan performansına etki eden personel güçlendirmenin ve organizasyonel yeniliğin tüm alt boyutları önce ayrı sonrada birlikte ele alınarak çalışan performansına etkisi ölçülmüştür.

\subsection{Literatür Çalışmaları}

Çavuş ve Akgemci'nin (2018) Türkiye'deki 500 Büyük Sanayi Kuruluşu içinde çalışan temsilen seçilen 280 orta ve alt düzey yöneticiler üzerine yaptıkları işletmelerde personel güçlendirmenin örgütsel yaratıcılık ve yeniliğe etkisini araştıran çalışmalarında personel güçlendirme tek faktörde ele alınarak örgütsel yeniliğe etkisinin $\% 47,8$ olduğu bulunmuştur.

Rao ve Weintraub (2013) geliştirdiği yenilikçilik anketi ile organizasyonlarda çalışanların inovasyon kültürü algılarını örgüt değerlerini, örgüt iklimi, davranışlar, süreçler, kaynaklar ve başarılar olarak altı performans kriteri ile ölçümlemiştir.

Erdem, Gökdeniz ve Met (2011) Antalya 'da faaliyet gösteren beş yıldızlı 44 adet otel işletmesi örneklemi ile yaptıkları anket çalışmasında, yenilikçilik ile işletme performansı arasında olumlu ve anlamlı bir ilişki bulmuşlardır. Literatürde personel güçlendirmenin ve organizasyonel yeniliğin olduğu işletmelerde çalışan performansının nasıl etkilendiğini ölçen çalışma bulunmamaktadır. Bu yüzden araştırma modelinde çalışan performansına etki eden personel güçlendirmenin ve organizasyonel yeniliğin tüm alt boyutları önce ayrı sonrada birlikte ele alınarak çalışan performansına etkisi ölçülmüştür.

Özer ve Akça (2007) yaptıkları görgül araştırma ile organizasyonel performans ile kurumsal kaynak planlamasının uygulama başarısı arasındaki ilişkiyi 236 işletmeden sağlanan verilerle incelemişlerdir. Yenilik özelliklerdeki artış kurumsal kaynak planlama uygulamalarındaki başarıyı artırmakta ve yenilikçi özellikler organizasyonel performansı üzerinde anlamlı etki etmektedir. Yenilik özümseme algısını oluşturan bağımsız değişkenlerin yenilikçi iş performansı üzerinde etkisi test edilmiştir. Ortaya çıkartılan analizler neticesinde; görece avantajı ve uyum bağımsız değişkeni yenilikçi iş performansı bağımlı değişkeni üzerinde en etkili olan yenilik özümseme algısını oluşturan etken olduğu bulunmuştur. Yenilikçi iş performansı bağımlı değişkeni, yenilik özümseme algısını oluşturan bağımsız değişkenler ile tecrübe edilebilirlik ve gönüllülük bağımsız değişkenleri hariç, orta düzeyde ve güçlü düzeyde pozitif yönde ilişkileri mevcuttur.

Özen ve Bingöl'ün (2007) küçük ve orta ölçekli 112 imalat sanayi işletmesi üzerinde yaptığ araştırmada firmaların organizasyonel yenilik oranlarında ürün yeniliği yüzde $56,3^{\prime}$ tür. Pazar yeniği yüzde $45,5^{\prime}$ dir. Yüzde 44,6 ile süreç yeniliği üçüncü sırada yer almaktadır. En son sırada yüzde 42 ile organizasyonel yenilik bulunmuştur. Firmaların eğitim programları düzenlemesi, üretimde ve satışta bilgi teknolojilerini kullanıyor olmaları ve bilgisayar donanımlarına sahip olmaları ile yenilikçilik unsurları arasında anlamlı ilişkiler bulunmuştur.

Lytle ve Timmerman (2006), bankalarda örgütsel hizmet odaklılığın örgütsel performans üzerindeki etkisini inceleyen çalışmada, örgütsel hizmet odaklı oluşun örgütsel performansın tüm boyutları üzerinde karlılık, hizmetin kalitesi, yeni müşteriler ve ticari hesaplar üzerinde etkili olduğunu tespit edilmiştir.

\section{YÖNTEM}

$\mathrm{Bu}$ bölüm araştırmamızın evreni ve örneklemi hakkında bilgi vermektedir. Verilerin elde edilmesi ve analizinde kullanılan yöntemler hakkında bilgi verilerek kullanılan ölçeklerin geçerlilik ve güvenilirlik analizleri sunulmuştur. Araştırmanın modeli ve hipotezleri açıklanmıştır.

\subsection{Evren ve Örneklem}

$\mathrm{Bu}$ araştırmanın evreni Kocaeli ilinde faaliyet gösteren Arçelik A.Ş.'nin yan sanayi ürünlerini oluşturan ve 300 çalışanı olan Tekkan Anonim Şirketidir. Çalışma evreninin bu firma olmasındaki temel neden firmada çalışan öğrencimizin gönüllü olarak araştırmamıza firma yetkililerinden izin alarak destek vermesidir. Kolayda örnekleme tekniği kullanılan araştırmada 300 çalışana anket dağıtılmış ve gelen 189 anketten 14 tanesi eksik olduğu için değerlemeden çıkartılmış ve kalan 175 anket değerlemeye alınmıştır. Evren sayısının bilindiği örneklem büyüklüğümüzün yeterliliğini gösteren kaynaklardan elde edilen bilgiye göre 169 kişiye ulaşılması gerekmektedir (Altunışık ve diğ., 2010). Anket dönüşleri ile ve değerlemeye alınan anket sayımız 


\section{G. Konakay - A. Akdemir - A.Ç. Mercanlığlu 13/1 (2021) 980-993}

örneklem yeterliliğinin üstündedir. Anket uygulaması, 20 Ekim 2019 ile 20 Kasım 2019 tarihleri arasında uygulanmiştır.

\subsection{Verilerin Toplanması ve Analizi}

Dört bölümden oluşan anket formu ile birinci elden veriler toplanmak suretiyle katılımcılara uygulanmıştır. Verilerin analiz edilmesinde SPSS 16,0 programı kullanılmış, tüm ölçekler için geçerlik ve güvenilirlik analizleri yapılmıştır. Çalışmada değişkenler arası ilişki ve etki düzeyini ölçmek amaçlı faktör analizi, korelasyon ve regresyon analizleri yapılmıştır.

Anket formunun ilk bölümünde, katılımcıların kişisel bilgileri; cinsiyet, medeni durum, yaş grupu, eğitim düzeyi ve çalışma yılı yer almaktadır. Diğer bölümlerde, ölçeklerin soruları bulunmaktadır.

Çalışanlarda personel güçlendirme ölçümünde Spreitzer'in (1995) anlam, yeterlilik, seçim ve etki boyutlarından oluşan 12 soruluk Psikolojik Güçlendirme Ölçeği kullanılmıştır. Personel güçlendirme ölçeğinin KMO değeri ,859'dir. Bu değer değişkenlerin faktör analizine uygunluğunun mükemmel seviyede olduğunun göstergesidir. Bartlett Küresellik Testi (Ki-Kare: 1,405E3; sd: 66; Sig.: 0,000) ölçeğin faktör analizi için uygun olduğunu göstermektedir. Ölçeğin açıklanan varyansı \%80,994 dür. Ölçeğin güvenilirlik düzeyi olan Cronbach's Alpha değeri ,895' tir. Tablo 1'de ölçeğin faktör değerleri yer almaktadır. Ölçek orjinalinde olduğu gibi dört boyut olarak ve yüksek faktör yükleri ile sınıflanmıştır.

\section{Tablo 1: Personel Güçlendirme Ölçeği Faktör Yükleri}

\begin{tabular}{|c|c|c|c|}
\hline $\begin{array}{l}\text { Faktör } \\
\text { Adı }\end{array}$ & PERSONEL GÜÇLENDİRME SORULARI & \begin{tabular}{|l} 
Faktör \\
Yükleri
\end{tabular} & $\begin{array}{l}\text { Faktör } \\
\text { Açıklayıcılığı } 1\end{array}$ \\
\hline 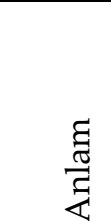 & $\begin{array}{l}\text { 1.Yaptığ iş benim için çok önemlidir. } \\
\text { 2.İşimle ilgili faaliyetler benim için şahsi anlam taşır. } \\
\text { 3.Yaptığım iş benim için anlamlıdır. } \\
\text { 4.İşimle ilgili yeteneğime güveniyorum. }\end{array}$ & $\begin{array}{l}0,879 \\
0,868 \\
0,794 \\
0,789\end{array}$ & 29,026 \\
\hline 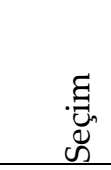 & $\begin{array}{l}\text { 12.Bölümümde olup bitenler üzerinde önemli derecede etki sahibiyim. } \\
\text { 11.Kendi bölümümdeki olaylar üzerinde kontrol sahibiyim. } \\
\text { 10.Bölümümde olup bitenler üzerinde etkim büyüktür. }\end{array}$ & $\begin{array}{l}0,912 \\
0,848 \\
0,735 \\
\end{array}$ & 20,604 \\
\hline $\overrightarrow{\vec{y}}$ & $\begin{array}{l}\text { 8.İșimi nasıl yapacağımla ilgili kararları kendim verebiliyorum. } \\
\text { 9.İșimi yaparken farklı yaklaşımları seçme konusunda özgürüm. } \\
\text { 7.İşimi nasıl yapacağımı belirlemede özgürüm. }\end{array}$ & $\begin{array}{l}0,877 \\
0,796 \\
0,641\end{array}$ & 18,271 \\
\hline : & $\begin{array}{l}\text { 6.İșimi yapmak için gerekli olan becerilerde uzmanlaştım. } \\
\text { 5.İşimle ilgili faaliyetleri gerçekleştirmek gerekli yeteneklere } \\
\text { sahip olduğumdan eminim }\end{array}$ & $\begin{array}{l}0,752 \\
0,717\end{array}$ & 13,093 \\
\hline & & Toplam & 80,994 \\
\hline
\end{tabular}

Çalışanların İş performansı ise 4 soruluk Kirkman ve Rosen (1999) ölçeği ile ölçülmüştür. İş performansı ölçeğinin KMO değeri ,771'dir. Bu değer değişkenlerin faktör analizine uygunluğunun mükemmel seviyede olduğunun göstergesidir. Bartlett Küresellik Testi ((Ki-Kare: 208,744; sd: 6; Sig.: 0,000) ölçeğin faktör analizi için uygun olduğunu göstermektedir. Ölçeğin açıklanan varyansı \%61,975' dir. Ölçeğin güvenilirlik düzeyi olan Cronbach's Alpha değeri ,793' tür. Tablo 2 'de ölçeğin tek boyut olan faktörünün değerleri yer almaktadir. 
G. Konakay - A. Akdemir - A.Ç. Mercanlığlu 13/1 (2021) 980-993

Tablo 2: İş Performansı Ölçeği Faktör Yükleri

\begin{tabular}{|c|c|c|c|}
\hline Faktör Adı & İŞ PERFORMANSI SORULARI & $\begin{array}{l}\text { Faktör } \\
\text { Yükleri }\end{array}$ & \begin{tabular}{|c|} 
Faktör \\
Açıklayıcılığ
\end{tabular} \\
\hline 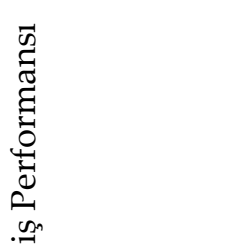 & $\begin{array}{l}\text { 19. Mutlaka kalite standartlarında ya da üzerinde ürünler } \\
\text { üretirim. } \\
\text { 17. Hedeflerimi gerçekleştiririm ya da aşarım. } \\
\text { 18. Problem çıtığında hızla çözerim. } \\
\text { 16.İşlerimi zamanında tamamlarım. }\end{array}$ & $\begin{array}{c}0,867 \\
0,794 \\
0,752 \\
0,73\end{array}$ & 61,975 \\
\hline \multicolumn{4}{|c|}{ Toplam } \\
\hline
\end{tabular}

Çalışanların organizasyonel yenilik performansı Wang ve Ahmet'in 2004 yılında geliştirdiği 17 soruluk organizasyonel yenilik ölçeği ile ölçülmüştür. Organizasyonel yenilik ölçeğinin KMO değeri ,865'tir. Bu değer değişkenlerin faktör analizine uygunluğunun mükemmel seviyede olduğunun göstergesidir. Bartlett Küresellik Testi (Ki-Kare: 809,246; sd: 66; Sig.: 0,000) ölçeğin faktör analizi için uygun olduğunu göstermektedir. Ölçeğin açıklanan varyansı \%61,601' dir. Ölçeğin güvenilirlik düzeyi olan Cronbach's Alpha değeri ,905' tir. Tablo 3 'de ölçeğin faktörleri ve faktör değerleri yer almaktadır.

Tablo 3: Organizasyonel Yenilik Ölçeği Faktör Yükleri

\begin{tabular}{|c|c|c|c|}
\hline Faktör Adı & ORGANIZASYONEL YENILİKÇILİK SORULARI & \begin{tabular}{|l} 
Faktör \\
Yükleri
\end{tabular} & $\begin{array}{l}\text { Faktör } \\
\text { Açıklayıc1lığı }\end{array}$ \\
\hline 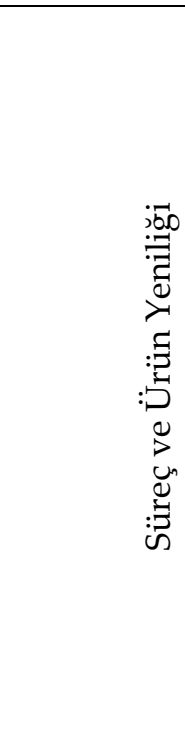 & $\begin{array}{l}\text { 1.İşletmemiz yeni ürün ve hizmet geliştirmede sektör öncüsüdür. } \\
\text { 2.Geliştirdiğimiz yeni ürünler ve hizmetler müşteriler tarafından } \\
\text { genellikle yeni/orijinal/alışılmamış olarak algılanır. } \\
\text { 3.Rakiplerimiz ile karşılaştırıldığında, işletmemiz son beş yıl içinde } \\
\text { daha fazla yenilikçi ürünler ve hizmetler tanıtmıştır. } \\
\text { 6.İşletmemiz üretim methodlarını rakiplerimize kıyasla daha } \\
\text { büyük bir hızla değiştirir. } \\
\text { 7.Son beş yıl içinde, işletmemiz tarafından birçok yeni yönetim } \\
\text { yaklaşımı geliştirilmiştir. } \\
\text { 9.Son geliştirdiğimiz yeni ürünler ve hizmetler bir önceki ürünler } \\
\text { ve hizmetlerde sadece küçük değişiklikler yapılarak } \\
\text { oluşturulmuştur. } \\
\text { 11.Rakiplerimiz ile karşılaştırıldığında, ürünlerimizin pazarlama } \\
\text { programı pazarda devrim niteliğindedir. }\end{array}$ & $\begin{array}{l}0,789 \\
0,774 \\
0,719 \\
0,578 \\
0,579 \\
0,559 \\
0,579\end{array}$ & 28,145 \\
\hline 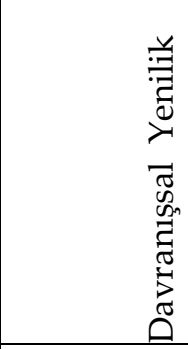 & $\begin{array}{l}\text { 12. Yeni ürün ve hizmet tanıtımlarında işletmemiz en son } \\
\text { teknolojiyi kullanır. } \\
\text { 13. İş yapış tarzımızda yeni yöntemler denemek istediğimizde } \\
\text { yöneticilerimizden büyük destek alırız. } \\
\begin{array}{l}\text { 14. İşletmemizde işleri değişik bir yolla yapan kişilere tolerans } \\
\text { gösteririz. }\end{array}\end{array}$ & 0,724 & 21,729 \\
\hline 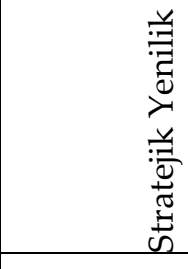 & $\begin{array}{l}\text { 17.İşletmemizde ArGe ve ürün geliştirme kaynakları, } \\
\text { yeni ürünler ve hizmetler geliştirmek için yeterli değildir. } \\
\text { 20. Yeni iş yapış yöntemleri gördüğümüzde bunları en son } \\
\text { uygulayan işletme oluruz. }\end{array}$ & 0,656 & 11,727 \\
\hline & & Toplam & 61,601 \\
\hline
\end{tabular}


G. Konakay - A. Akdemir - A.Ç. Mercanlığlu 13/1 (2021) 980-993

\subsection{Araştırma Modeli ve Hipotezler}

Ölçekler üzerinde gerçekleştirilen faktör ve güvenilirlik analizlerinin ardından araştırma modeli meydana getirilmiştir. Personel güçlendirme ile birlikte organizasyonel yeniliğin çalışan performansı üzerinde ne derece etkili olup olmadığı araştırmanın ana hipotezleri ile birlikte şu alt hipotezler ile test edilecektir:

Hı: Organizasyonel yenilik faktörü olan süreç ve ürün yeniliği ile iş performansı arasında anlamlı bir ilişki vardır.

$\mathrm{H}_{2}$ : Organizasyonel yenilik faktörü olan davranışsal yenilik ile iş performansı arasında anlamlı bir ilişki vardır.

$\mathrm{H}_{3}$ : Organizasyonel yenilik faktörü olan stratejik yenilik ile iş performansı arasında anlamlı bir ilişki vardır.

$\mathrm{H}_{4}$ : Personel güçlendirmenin anlam faktörü ile iş performansı arasında anlamlı bir ilişki vardır.

Hs: Personel güçlendirmenin seçim faktörü ile iş performansı arasında anlamlı bir ilişki vardır.

$\mathrm{H}_{6}$ : Personel güçlendirmenin etki faktörü ile iş performansı arasında anlamlı bir ilişki vardır.

$\mathrm{H}$ 7: Personel güçlendirmenin yeterlilik faktörü ile iş performansı arasında anlamlı bir ilişki vardır.

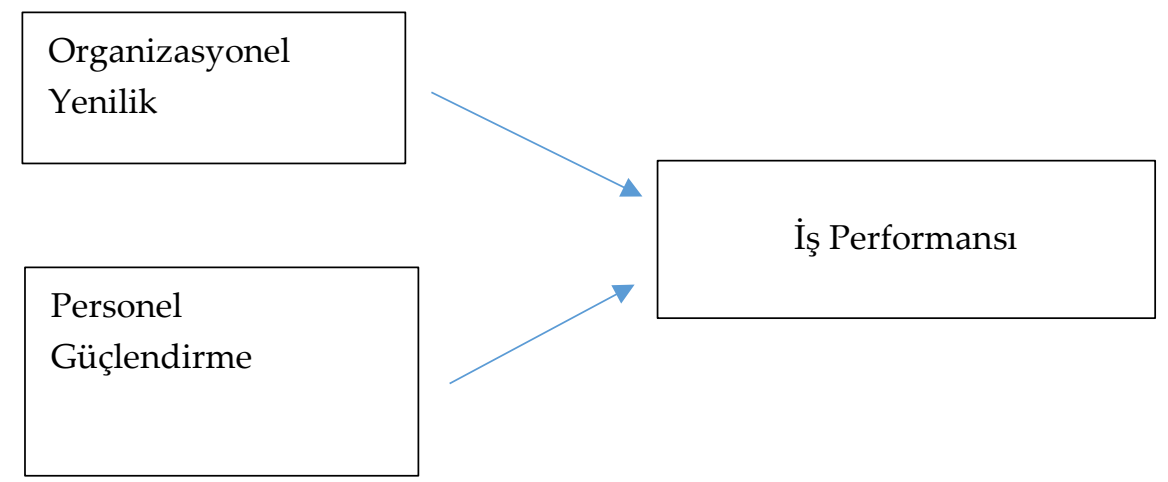

Şekil 1: Araştırma Modeli

\subsection{Araştırmanın Sınırlılıkları}

Araştırmanın sadece Kocaeli ilinde tek bir firmada organizasyonel yenilik ve personel güçlendirme uygulamalarının mavi ve beyaz yaka çalışanların iş performanslarına etkisini göstermesi ve özel sektör işgörenlerine uygulanması araştırma sınırlılığımızın ilk göstergesidir. Araştırmada elde edilen sonuçlar sadece 175 özel sektör çalışanlarının yanıtları ile sınırlıdır. Çalışmanın kısıtlı zaman da uygulanması zaman yönünden yaşanan sınırlılıktır. Araştırmamız 20 Nisan 2019 ile 20 Mayıs 2019 tarihleri arasında Tekkan A.Ş.'den araştırma izni alınarak gerçekleştirilmiştir.

\section{BULGULAR}

Bu bölümde, araştırmaya katılmış olan kişilerin demografik özelliklerine ilişkin bulgulara yer verilmiş ve hipotezlerin test edilmesi sonucunda ortaya çıkan analiz sonuçları açıklanmıştır.

Tablo 4: Demografik Değişkenler

\begin{tabular}{|l|c|c|}
\hline Cinsiyet & $\mathrm{n}$ & $\%$ \\
\hline Erkek & 80 & 45,7 \\
Kadın & 95 & 54,3 \\
\hline Medeni Durum & $\mathrm{n}$ & $\%$ \\
\hline Evli & 100 & 57,1 \\
Bekar & 75 & 42,9 \\
\hline Eğitim & $\mathrm{n}$ & $\%$ \\
\hline İlkokul/ortaokul & 77 & 44 \\
lise & 65 & 37,1 \\
Üniversite & 30 & 17,1
\end{tabular}


G. Konakay - A. Akdemir - A.Ç. Mercanlıŏlu 13/1 (2021) 980-993

\begin{tabular}{|l|c|c|}
\hline Lisansüstü/Doktora & 3 & 1,7 \\
\hline Toplam & 175 & 100 \\
\hline Yaş Aralığ1 & $\mathrm{n}$ & $\%$ \\
\hline 19 yaş altı Z Kuşağı & 8 & 4,6 \\
\hline 20-39 Y Kuşağ1 & 103 & 58,9 \\
\hline $40-54$ X Kuşağ1 & 62 & 35,4 \\
\hline 55-63Baby Boomers Kuşağı & 2 & 1,1 \\
\hline Toplam & 175 & 100 \\
\hline Çalışma Yılı & $\mathrm{n}$ & $\%$ \\
\hline $1-5$ yıl & 112 & 64 \\
\hline 6-10 yıl & 37 & 21,1 \\
\hline $11-15$ yıl & 15 & 8,6 \\
\hline 16 yıl ve üstü & 11 & 6,3 \\
\hline Toplam & 175 & 100 \\
\hline
\end{tabular}

Tablo 4'de göre çalışmada 175 kişinin \%45,7'si erkek \%54,3'ü kadındır. Çalışanların \%57, 1'i evli \%42,9'u bekardır. Yaş dağılımına bakıldığında 19 yaş altını oluşturan $Z$ kuşağı \%4,6'lık kesimi oluşturmaktadır. \% 58,9'u 20-39 yaş aralığını oluşturan $Y$ kuşağı çalışanlarıdır. 40-54 yaş aralığından oluşan $X$ kuşağı \%35'4'tür. 55-63 yaş aralığında bulunan iki kişidir ve bunlar \%1,1'lik kesim ile en az grubu oluşturmaktadır. Çalışanların eğitim durumu \% 44 ile ilkokul/ortaokul, \%37'1 ile lise, \%17,1 ile üniversite ve \%1,7 ile Lisansüstü/Doktora olduğu görülmektedir. Araştırmaya katılanların çalışma yıllarına bakıldığında en büyük oran \%64 ile 1-5 yıl aralığındadır. 6-10 yıl çalışanların oranı \%21,1, 11-15 yıl çalışanlar \%8,6, 16 yıl üstü çalışanlar ise \%6,3'lük kesimi oluşturmaktadırlar.

Organizasyonel yenilik faktörünün boyutları olan süreç ve ürün yeniliği, davranışsal yenilik ve stratejik yenilik boyutlarının iş performansı arasında anlamlı bir ilişki olup olmadığ ${ }_{1} \mathrm{H}_{1}, \mathrm{H}_{2}$ ve $\mathrm{H}_{3}$ hipotezleri regresyon analizi ile bakılmıştır.

Tablo 5 : Organizasyonel Yeniliğin İş Performansı Üzerindeki Regresyon Sonucu

\begin{tabular}{|l|l|l|l|}
\hline & \multicolumn{4}{|l|}{ Bağımlı Değişken : İş Performansı } \\
\hline Faktörler & Beta B & $\mathrm{t}$ & $\mathrm{p}$ \\
\hline (Constant) & & 7,567 &, 000 \\
\hline 1.Süreçte Ürün Yeniliğgi & $\mathbf{3 5 0}$ & $\mathbf{4 , 0 4 0}$ & $\mathbf{, 0 0 0}$ \\
\hline 2. Davranışsal Yenilik &, 131 & 1,506 &, 134 \\
\hline 3.Stratejik Yenilik &, 081 & 1,170 &, 244 \\
\hline & $\mathrm{R}:, 469 \quad \mathrm{R}^{2}:, 220 \quad$ F: 16,055 & Sig:, 000 \\
\hline
\end{tabular}

Tablo 5' deki regresyon analizi sonucunda organizasyonel yenilik faktörleri ile iş performansı bağımlı değişkeni arasında (R: 0,469) orta dereceli korelasyon olduğu ve $\left(R^{2}: 0,220\right)$ bu faktörün iş performansının \% 22 sini açıkladığı görülmektedir.

Süreçte ürün yeniliği faktörü iş performansını $(p=0,000)$ anlamlı ve $(\beta=0,350)$ beta katsayısı değerinde pozitif yönde etkilemektedir. Davranışsal yenilik faktörü ile İş performansı arasındaki ilişki $(p=0,134)$ ve $(\beta=0,131)$ olduğu için anlamlı değildir. Stratejik yenilik faktörü ile iş performansı arasındaki ilişki de $(p=0,244)$ ve $(\beta=$ 0,081) olduğu için anlamlı bulunmamıştır.

Personel güçlendirme faktörünün boyutları olan anlam, seçim, etki ve yeterlilik boyutları ile iş performansı arasında anlamlı bir ilişki olup olmadığ $\mathrm{H}_{4}, \mathrm{H}_{5}, \mathrm{H}_{6}$ ve $\mathrm{H}_{7}$ hipotezlerine regresyon analizi ile test edilmiştir. 
G. Konakay - A. Akdemir - A.Ç. Mercanlıŏlu 13/1 (2021) 980-993

Tablo 6 : Personel Güçlendirmenin İş Performansı Üzerindeki Regresyon Sonucu

\begin{tabular}{|c|c|c|c|}
\hline & \multicolumn{3}{|c|}{ Bağımlı Değişken : İş Performansı } \\
\hline Faktörler & Beta B & $\mathrm{t}$ & $p$ \\
\hline (Constant) & & 8,867 &, 000 \\
\hline 1.Anlam & 326 & 3,645 & ,000 \\
\hline 2. Seçim & ,338 & 4,272 & ,000 \\
\hline 3.Etki &,- 122 & $-1,463$ & ,145 \\
\hline 4. Yeterlilik & 227 & 2,502 & ,013 \\
\hline \multicolumn{4}{|r|}{ Sig: ,000 } \\
\hline
\end{tabular}

Tablo 6' daki regresyon analizi sonucunda personel güçlendirme faktörlerinin iş performansı bağımlı değişkeni arasında (R: 0,627) orta dereceli korelasyon olduğunu ve $\left(R^{2}: 0,393\right)$ bu faktörün yenilik performansının \%39,3'ünü açıkladığı görülmektedir.

Anlam faktörü İş performansını $(p=0,000)$ anlamlı ve $(\beta=0,230)$ beta katsayısı değerinde pozitif yönde etkilemektedir. Seçim faktörü iş performansını $(p=0,000)$ anlamlı ve $(\beta=0,231)$ beta katsayısı değerinde pozitif yönde etkilemektedir. Yeterlilik faktörü iş performansını $(p=0,013)$ anlamlı ve $(\beta=0,172)$ beta katsayısı değerinde pozitif yönde etkilemektedir. Etki faktörünün iş performansı üzerinde etkisi bulunmamaktadır $(\mathrm{p}=0,145$ ve $\beta=-, 122)$.

Tablo 7 : Organizasyonel Yenilik ve Personel Güçlendirmenin İş Performansı Üzerinde Çoklu Regresyon Sonucu

\begin{tabular}{|c|c|c|c|}
\hline & \multicolumn{3}{|c|}{ Bağımlı Değişken : İş Performansı } \\
\hline Faktörler & Beta B & $\mathrm{t}$ & $\mathrm{p}$ \\
\hline (Constant) & & 5,703 & 000 \\
\hline Süreçte Ürün Yeniliği & 157 & 1,964 & 051 \\
\hline Davranışsal Yenilik & 069 & 853 & ,395 \\
\hline Stratejik Yenilik & ,026 & 426 & 671 \\
\hline Anlam & ,276 & 3,081 & ,002 \\
\hline Seçim & ,328 & 4,123 & ,000 \\
\hline Etki & -168 & $-1,932$ & 055 \\
\hline Yeterlilik & ,179 & 1,962 & 051 \\
\hline \multicolumn{2}{|c|}{ R: , 651} & F: 17, & Sig: ,000 \\
\hline
\end{tabular}

Tablo 7'ye göre $\left(R^{2}=0,424\right)$ organizasyonel yenilik ve personel güçlendirme faktörleri iş performansını $\% 42,4^{\prime}$ ünü açıklamaktadır. Yapılan faktör analizi sonucunda süreç ve ürün yeniliği bir faktör altında toplanmıştır. Bu değişkenler birbirleriyle bağlantılı olduğu için süreçte ürün yeniliği olarak yeni faktör isimlendirilmiştir. Tek başına organizasyonel yeniliğin süreçte ürün faktörü iş performansı üzerinde etkili iken personel güçlendirmenin faktör boyutları ile birlikte ele alındığında ilişkisi olmadığı görülmektedir. $(R=0,651)$ Bağımlı ve bağımsız değişkenler arasında pozitif yönde orta derecede bir korelasyon görülmektedir $(p=, 000 ; p<0,01$ ve $F=17,574)$. Değişkenler arasındaki ilişki istatistiksel olarak anlamlıdır. Organizasyonel yenilik faktörü olan süreç ve ürün yeniliği ile iş performansı arasında anlamlı bir ilişki yoktur $(\beta=0,157 ; p=0,051) \quad$ H1 Hipotezi RED edilmiştir.

Organizasyonel yenilik faktörü olan davranışsal yenilik ile İş performansı arasında anlamlı bir ilişki yoktur $(\beta=0,069 ; p=0,395) \mathbf{H}_{\mathbf{2}}$ Hipotez RED edilmiştir.

Organizasyonel yenilik faktörü olan stratejik yenilik ile iş performansı arasında anlamlı bir ilişki yoktur $(\beta=0,026 ; p=0,671) \mathbf{H}_{3}$ Hipotez RED edilmiştir.

Personel güçlendirmenin anlam faktörü ile iş performansı arasında anlamlı bir ilişki olduğu görülmektedir $(\beta=0,276 ; p=0,002)$. $\mathbf{H}_{4}$ Hipotezi KABUL edilmiştir. 
Personel güçlendirmenin seçim faktörü ile iş performansı arasında anlamlı bir ilişki olduğu görülmektedir $(\beta=0,328 ; \mathrm{p}=0,000)$. $\mathbf{H}_{5}$ Hipotezi KABUL edilmiştir.

Personel güçlendirmenin etki faktörü ile iş performansı arasında anlamlı bir ilişki olmadığı görülmektedir $(\beta=-, 168 ; p=0,055)$. H$_{6}$ Hipotezi RED edilmiştir.

Personel güçlendirmenin yeterlilik faktörü ile iş performansı arasında anlamlı bir ilişki olmadığı görülmektedir $(\beta=0,179 ; p=0,051)$. H7 Hipotezi RED edilmiştir.

\section{SONUÇ VE TARTIŞMA}

$\mathrm{Bu}$ araştırma ile personel güçlendirme ve organizasyonel yeniliğin çalışan performansı üzerindeki etkisi incelenmiştir. Öncelikle personel güçlendirmenin boyutları ile çalışan performansı ilişkisine bakılmıştır. Organizasyonel yeniliğin boyutları ile çalışan performansına etkisi bakıldıktan sonra çoklu regresyon ile her iki ölçeğin boyutları birlikte ele alınarak çalışan performansına etkisine bakılmıştır. $(R 2=0,424)$ organizasyonel yenilik ve personel güçlendirme faktörleri iş performansını \%42,4 olarak etkilediği gözlemlenmiştir.

Araştırma Verileri SPSS 16,0 programına kaydedilmesinin ardından personel güçlendirme, organizasyonel yenilik v kullanılmış, tüm ölçekler için e çalışan performansı ölçeklerinin geçerlik ve güvenilirlik analizleri yapılmıştır. Araştırmada kullanılan bütün ölçeklerin geçerlilik ve güvenilirlikleri yüksek çıkmıştır. Çalışmada değişkenler arası ilişki ve etki düzeyini ölçmek amaçlı faktör analizi, korelasyon ve regresyon analizleri yapılmıştır.

Örgüt kültürünün örgütsel yenilik ve personel güçlendirme ile olan ilişkisinin Şanlıurfa'daki bir aşı merkezinde araştırıldığ 1 çalışmada Örgüt kültürü ile personel güçlendirmenin "anlam" alt boyutu arasında anlamlı bir ilişki görülmüştür (Zengin ve Kaygın, 2019) . Araştırmanın örgütsel yenilik ve personel güçlendirme boyutları ile araştırmamızın örgütsel yenilik ve personel güçlendirme boyutları benzerlik göstermektedir. Personel güçlendirmenin "anlam" boyutunun yanı sıra "seçim" boyutuyla da iş performansı arasında ilişki çıkmıştır. Organizasyonlarda yapılan yeniliklerde ilerleme, gelişme ve bunun sürdürülebilir olmasını isteniyor ise yeniliğe etki eden parametrelerin ölçümlenebilir olması oldukça önem arz etmektedir. Her organizasyon temel öz yeteneklerine göre farklılık arz ettiği için yapılan yeniliklerden etkilenen değişkenlerinde her organizasyon için farklılık göstermesi kaçınılmazdır. İlk önce organizasyonel yenilik faktörleri ile iş performansı arasındaki ilişkiye bakıldığında süreç ve ürün yeniliği faktörü iş performansı üzerinde etkili iken bu etki personel güçlendirme ile birlikte ele alındığında zayıfladığı görülmüştür. Personelin güçlendirilmesi iş performansı üzerinde organizasyonel yenilikten daha baskın hale gelmektedir. Organizasyonel yeniliğin davranışsal yenilik ve stratejik yenilik faktörleri ile ilişkili olmadığ ${ }_{1}$ her iki regresyon modelinde de gözükmüştür. Personel güçlendirmenin dört faktöründen ikisi olan anlam ve seçim faktörleri her iki regresyon tablosunda pozitif orta düzeyde ilişkili çıkmıştır. Personel güçlendirmenin etki ve yeterlilik faktörleri ile çalışanların iş performaslarının ölçümünde herhangi bir ilişki tespit edilememiştir. Çalışmada ele alınan organizasyonel yenilik faktörlerindeki gelişmelerin personel güçlendirme uygulamaları ile birlikte değerlendirilmesi uygun bulunmuş ve neticesi için iş performansına etkisi olup olmadığı incelenmiştir. Yapılan incelemeler sonucunda organizasyonel yenilik ve personel güçlendirmenin iş performansı üzerinde \% 42,4'lük orta düzeyde pozitif bir ilişkisi olduğu sonucuna ulaşılmıştır.

Yıldırım ve Karabey (2016) araştırmalarında personel güçlendirmenin ürün, süreç, strateji ve pazar yeniliği üzerindeki etkisini hiyerarşi kültürünü azaltarak biçimlendirdiğini ve yenilik türleri üzerindeki etkisini azalttığını Erzurum ilinde 419 otel çalışanları üzerinde yapmış oldukları araştırmada bulmuşlardır. Personel güçlendirmenin yenilik üzerinde olumlu etkisi olduğu bilinmektedir. Bu etkinin açığa çıkmasında çalışanların iş performansı önemli bir etkendir. Bunun için araştırmamızda personel güçlendirme ve organizasyonel yenilik birlikte iş performansını olumlu etkilediği düşünülmüş literatürdeki diğer olumlu etkilerin sonuçları gibi bir sonuç elde edilmiştir.

Personel güçlendirmenin iş memnuniyetini pozitif olarak etkilediği (Ning ve diğg., 2009), işe bağlllık ile personel güçlendirmenin psikolojik ve yapısal boyutlarındaki pozitif ilişki olduğu (DiNapoli ve diğ..., 2016) tespit edilmiştir. İş bağlılığı, iş memnuniyeti gibi unsurlara personel güçlendirmenin etkisi çalışan performansın da etkide bulunabileceğinin araştırılmasını desteklemektedir. 


\section{G. Konakay - A. Akdemir - A.Ç. Mercanlığlu 13/1 (2021) 980-993}

Araştırmanın farklı sektörlerde ve farklı şehir ve bölgelerde yapılması araştırma sonuçları, çalışılan sektör, kuşak farklılıklarındaki değişimi göstermesi açısından literatüre büyük katkı sağlayacağı düşünülmektedir. Farklı sektör çalışanlarının ve farklı yönetim kademelerinde bulunan organizasyon çalışanların etkilendikleri yenilik faktörleri ve etki derecelerinin açığa çıkarılması, organizasyondaki liderlik türlerinin yenilik davranışına katkısı incelenmesi gerekli önemli konulardandır. Organizasyonel yenilik ve personel güçlendirme kavramlarının örgütsel vatandaşlık, örgütsel bağlılık, çatışma yönetimi gibi konularla ilişkileri incelenebilir. Farklı şehir ve farklı sektörlerde organizasyonel yenilik ve personel güçlendirmenin iş performansına etkileri çalışılabilir.

\section{KAYNAKÇA}

Ahmed, P. (1998). Culture and climate for innovation. European Journal of Innovation Management. Volume 1, Number 1, 30-43.

Altunışık, R., Çoşkun, R., Bayraktaroğlu, S., Yıldırım, E. (2010). Sosyal bilimlerde araştırma yöntemleri SPSS uygulamalı, 6.Gelişmiş Baskı, Sakarya Yayıncılık, Sakarya.

Aghayeva, İ. (2019). Yenilik Yönetiminde Temel Kavramlar: Yenilikçilik, Girişimcilik, Yaratıcılık, Yayınlanmamış Yüksek Lisans Tezi, Elazı̆̆: Fırat Üniversitesi Sosyal Bilimler Üniversitesi.

Bettencourt, Lance \& Ulwick, Anthony. (2008). The customer-centered innovation map. Harvard business review. 86. 109-14, 130.

Camisón, C., Villar-López, A. (2014). Organizational Innovation as an Enabler of Technological Innovation Capabilities and Firm Performance. Journal of Business Research, 67(1), 2891- 2902.

Coleman, H.J. (1996). Why Employee Empowerment is not just a fad. Leadership \& Organization Development Journal, 17/4,29-36

Cummings, A., \& Oldham, G. R.(1997). Enhancing Creativity: Managing Work Contexts For The High Potential Employee. California Management Review, 40(1), 22-38.

Çavuş M.F., Akgemci, T. (2008). İşletmelerde Personel Güçlendirmenin Örgütsel Yaratıcılık Ve Yenilikçiliğe Etkisi: İmalat Sanayiinde Bir Araştırma. Selçuk Üniversitesi Sosyal Bilimler Dergisi, Sayı: 20, 229-244.

DiNapoli, J. M., O'Flaherty, D., Musil, C., Clavelle, J. T. ve Fitzpatrick, J. J. (2016). The relationship of clinical nurses' perceptions of structural and psychological empowerment and engagement on their unit. Journal of Nursing Administration, 46(2), 95-100.

Eğe A. A. (2002). OECD Ülkelerinde Yenilik Sistemleri ve Türkiye İçin Durum Değerlendirilmesi. Ankara: DPT.

Eminoğlu, G., (2011). Örgütsel Kültür ve Yenilikçiliğin Performansa Etkilerini İncelemeye Yönelik Bir Araştırma. Yayımlanmamış Yüksek Lisans Tezi. Eskişehir: Osmangazi Üniversitesi, Sosyal Bilimler Enstitüsü.

Erdem, B , Gökdeniz, A , Met, Ö . (2011). Yenilikçilik Ve İşletme Performansı İlişkisi: Antalya'da Etkinlik Gösteren 5 Yıldızlı Otel İşletmeleri Örneği . Dokuz Eylül Üniversitesi İktisadi İdari Bilimler Fakültesi Dergisi, 26 (2) , 77-112 . Retrieved from https://dergipark.org.tr/tr/pub/deuiibfd/issue/22779/243138

Eren, H., Karaca S., Kılıç A. (2015). Firma İçi Ve Dıı̧ı Kaynakların Organizasyonel Yenilik Geliştirmedeki Etkileri, Yönetim ve Ekonomi Araştırmaları Dergisi. C.13 S.3 , Eylül, 157-179.

Freeman, C. (1989). Technology Policy and Economic Performance. Great Britain: Pinter Publishers.

Ganter A. ve Hecker, A.(2014). Configurational Paths to Organizational Innovation: Qualitative Comparative Analyses of Antecedents and Contingencies. Journal of Business Research, 67, 1285-1292.

Genç, N. (2004). Yönetim ve Organizasyon: Çağdaş Sistemler ve Yaklaşımlar. Ankara: Seçkin Yayınevi.

İmamoğlu, İ. K. (2012). Örgütsel Öğrenme Yeteneğinin Yenilik ve Firma Performansı Üzerine Etkisi. Yüksek Lisans Tezi, Kocaeli: Gebze Yüksek Teknoloji Enstitüsü. 


\section{G. Konakay - A. Akdemir - A.Ç. Mercanlığlu 13/1 (2021) 980-993}

Janssen, O. (2000). Job Demands, Perceptions of Effort-Reward Fairness and Innovative Work Behaviour. Journal of Occupational and Organizational Psychology. 73(3), 287-302.

Kara K. (2019). Ulusal Yenilik, Ulusal Rekabet ve Ulusal Yükseköğretim Başarı İlişkisi. Ankara: Gazi Kitabevi.

Karabulut, A. T.(2015). Stratejik Yenilik Yönetimi: İnnovasyon, Yenileşim, Yenilik. İstanbul: Papatya Yayınevi.

Kirkman, B. L., ve Rosen, B. (1999). Beyond Self-management: Antecedents and Consequences of

Team Empowerment. Academy of Management Journal, 42(1), 58-74

Krause, D. E. (2004). Influence-Based Leadership as A Determinant of The İnclination to Innovate and of Innovation-Related Behaviors: An Empirical Investigation, The Leadership QuarterlyLundvall, B. (2010). National systems of innovation : toward a theory of innovation and interactive learning (Vol.2). Anthem press.

Lundvall, B.A. (2010). National Systems Of İnnovation : Toward a Theory of Innovation and Interactive Learning (Vol.2). London; New York; Delhı: Anthem press.

Lytle, R. S ve Timmerman, J. E. (2006). service orientation and performance: an organizational perspective. Journal of Service Marketing, 20 (2): 136- 147.

Mert G.(2018). Organizasyonlarda yenilik yönetimi. Artikol Yayıncllk, İstanbul.

Nelson, R. R.(1993). National innavation systems: a comparative analysis. Oxford University Press.

Ning, S., Zhong, H., Libo, W. ve Qiujie, L. (2009). The impact of nurse empowerment on job satisfaction. Journal of Advanced Nursing, 65(12), 2642-2648.

OECD. (2005). Oslo manual-the measurement of scientific and technological activities: proposed guidelines for collecting and interpreting technological innovation data. OECD, Paris.

Özen Ü., Bingöl M., (2007). İşletmelerde Bilişim Teknolojileri Ve Yenilikçilik: Erzurum, Erzincan Ve Bayburt'taki Kobi'lerde Bir Araştırma. Atatürk Üniversitesi Sosyal Bilimler Enstitüsü Dergisi, C.10, S.2, 399- 417.

Özer, G. ve Akça, Y. (2007). Yenilikçi özelliklerin, kurumsal kaynak planlaması uygulama başarısına ve algilanan organizasyonel performans üzerine etkisi. Zonguldak Karaelmas Üniversitesi Sosyal Bilimler Dergisi 3 (5), 53-70.

Rao, J., \& Weintraub, J. R. (2013). How İnnovative is Your Company's Culture?. MIT Sloan Management Review, Spring Vol.54 No.3, 28-37

Reiner, G. (2004). Customer-Oriented Improvement and Evaluation of Supply Chain Processes Supported by Simulation Models. International Journal of Production Economics, (22) 381-395.

Robbins, T. L., Crino, M.D. \& Fredendal, L.D. (2002). An Integrative Model of The Empowerment Process. Human Resource Management Review, Vol:12, 419-443.

Shalley, C. E., \& Gilson, L. L. (2004). What leaders need to know: a review of social and contextual factors that can foster or hinder creativity. The Leadership Quarterly, 15(1), 33-53.

Spreitzer, G.M. (1995) "Psychological Empowerment in the Workplace: Dimensions, Measurement, and Validation" The Academy of Management Journal, 38(5):1442-1465.

Tekin, M., Güleş, H. K., Öğüt A.(2003). Teknoloji yönetimi. Nobel Yayın, Ankara.

Tidd, J., Bessant, J., Pavitt, K.(2005). Managing innovation: integrating technological, market and organizational change, 3rd Edition, John WileyESons, March.

Turanlı R. ve Sarıdoğan E.(2010). Bilim-teknoloji-inovasyon temelli ekonomi ve toplum. İstanbul Ticaret Odası Akademik Yayınları, Yayın No: 2010-2013, İstanbul.

Wang, C. L. and Ahmed, P. K. (2004). The development and validation of the organisational innovativeness construct using confirmatory factor analysis. European Journal of Innovation Management, 7(4):303313. 
G. Konakay - A. Akdemir - A.Ç. Mercanlığlu 13/1 (2021) 980-993

Yıldırım, F , Karabey, C . (2016). Örgüt Kültürünün Yeniliğe Etkisinde Personel Güçlendirmenin Biçimlendirici Rolü . Gazi Üniversitesi İktisadi Ve İdari Bilimler Fakültesi Dergisi , 18 (2) , 426-453 . Retrieved From Https://Dergipark.Org.Tr/Tr/Pub/Gaziuiibfd/İssue/28287/300470

Yıldız, S.(2011). Entellektüel sermayenin işletme performansına etkisi: bankacılık sektöründe bir araştırma. Anadolu Üniversitesi Sosyal Bilimler Dergisi, 11(3), 11-28.

Yuan, F., \& Woodman R. W. (2010). Innovative behavior in the workplace: the role of performance and image outcome expectations. Academy of Management Journal, 53(2), 323-342.

Zengin,Y., Kaygın, E. (2019). Örgüt Kültürünün Örgütsel Yenilik Ve Personel Güçlendirmeyle İlişkisi: Şanlıurfa'da Bir Araştırma. Elektronik Sosyal Bilimler Dergisi

Zerenler, M., Türker, N., Esen. Ş. (2007). Küresel Teknoloji, Araştırma-Geliştirme (Ar-Ge) Ve Yenilik İlişkisi. Selçuk Üniversitesi, Sosyal Bilimler Enstitüsü Dergisi, 17, 653-667. 